\title{
OSTEOSÍNTESIS DE FRACTURA DE ESPINA TIBIAL ASISTIDA CON ARTROSCOPÍA Y TORNILLO DE COMPRESIÓN TIPO HERBERT, REPORTE DE UN CASO Y REVISIÓN DE LITERATURA.
}

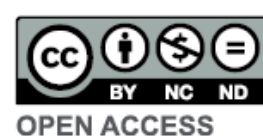

Este artículo está bajo una ícencia de Creative Commons de tipo Reconocimien- No comercial - Sin obras derivadas 4.0 International.

1. Hospital Quito $\mathrm{N}^{\circ} 1$ Polícia Nacional. Médico en función Hospitalaria. Quito, Ecuador

\section{ORCID ID:}

Portero Katherine Patricia

orcid.org/0000-0003-2657-6705

Pullupaxi Stefany Belén

orcid.org/0000-0003-4809-1821

* Corresponding author:

Portero Katherine Patricia

E-mail: kathph_22@hotmail.com

Article history: Manuscript presented at the I Clinical Case Contest - Hospital Vozandes Quito, February 27, 2021. CARE 2017 Check List statement: The authors
have real the CARE 2017 Check List and the manuscript was prepared and revised according to the CARE 2017 Checklist.

Conflict of interest: All authors declared that there are no conflicts of interest.

Financial disclosure: The authors have no financial relationships relevant to this article to disclose.

Forma de citar este artículo: Portero KP, Pullupaxi SB. OSTEOSÍNTESIS DE FRACTURA DE ESPINA TIBIAL ASISTIDA CON ARTROSCOPIAA Y TORNILLO DE COMPRESIÓN TIPO HERBERT, REPORTE DE UN CASO Y REVISIÓN DE LITERATURA. Rev Med Vozandes. 2021; 32 (1 Suppl 1): S3-S4

\section{Resumen}

Introducción: Las fracturas de la espina tibial tienen una prevalencia de 3 por cada 100.000 personas anualmente. Los traumatismos de alta energía son la principal causa, seguidos por los traumatismos de baja energía y en un $40 \%$ por traumatismos múltiples. Los estudios de imagen juegan un papel crucial para establecer el diagnostico. Es importante comprender que la radiografía por sí sola no permite una identificación correcta de la fractura, por lo que es necesario complementar con una Tomografía o RM. La clasificación de Meyers-McKeever divide a las fracturas por su grado de desplazamiento y la conminución en 4 tipos, y nos orienta en la decisión terapéutica. El manejo de estas fracturas depende de la morfología, afectación de tejidos blandos y el estado general del paciente. El tratamiento quirúrgico se considera principalmente para las fracturas desplazadas. Dentro de este abordaje, la técnica asistida por artroscopía ha reportado excelentes resultados. con una baja tasa de complicaciones, en comparación con las técnicas abiertas, a pesar de los escasos estudios para definir el tratamiento Gold estándar.

Descripción del Caso: Se reporta un caso clínico de un paciente de 32 años, con fractura de espina tibial posterior, intervenido quirúrgicamente con osteosíntesis asistida con artroscopía y con tornillo de compresión tipo Herbert 4.5 x 4.0 con imágenes artroscópicas intraoperatorias que demostraron la restauración de la congruencia articular, sin lesión de meniscos o ligamentos, valorando arcos de movilidad intraoperatorios de 0 a 90 grados. En su postquirúrgico mediato se realiza fisioterapia isométrica con flexión y extensión de la rodilla de 0 a 90 grados más fortalecimiento de psoas iliaco y cuádriceps para reanudar sus actividades en 2 meses posterior a su cirugía.

Conclusión: En la actualidad, no existe un consenso acerca de la técnica quirúrgica óptima debido a la falta de ensayos clínicos. Son necesarios más estudios, de mayor calidad y tamaño de muestra para establecer el Gold Standard en el tratamiento de las fracturas de la espina tibial. Sin embargo, vimos que al utilizar tornillos de compresión tipo Herbert se logra una compresión oportuna del fragmento fracturario en la reducción anatómica. Se realiza una revisión actualizada del tema y su manejo terapéutico. 
Keywords: Tibial Fractures, Fracture Fixation Internal, Bone Screws, Case Report

\section{Abstract \\ OSTEOSYNTHESIS OF A TIBIAL SPINE FRACTURE ASSISTED WITH ARTHROSCOPY AND HERBERT-TYPE COMPRESSION SCREW, A CASE REPORT AND LITERATURE REVIEW.}

Introduction: Tibial spine fractures have a prevalence of 3 per 100,000 people annually. High-energy trauma is the leading cause, followed by low-energy trauma and $40 \%$ by multiple trauma. Imaging studies play a crucial role in establishing the diagnosis. It is important to understand that radiography alone does not allow a correct identification of the fracture, so it is necessary to complement it with a CT or MRI scan. The Meyers-McKeever classification divides fractures by their degree of displacement and comminution into 4 types and guides us in the therapeutic decision. The management of these fractures depends on the morphology, soft tissue involvement and the general condition of the patient. Surgical treatment is primarily considered for displaced fractures. Within this approach, the arthroscopy-assisted technique has reported excellent results. with a low complication rate, compared to open techniques, despite the few studies to define the standard Gold treatment.

Case description: A clinical case of a 32-year-old patient with a posterior tibial spine fracture is reported, who underwent surgery with arthroscopicassisted osteosynthesis and a $4.5 \times 4.0$ Herbert-type compression screw with intraoperative arthroscopic images that demonstrated the restoration of joint congruence, without menisci or ligament injury, assessing intraoperative arches of motion from 0 to 90 degrees. In his mediate postsurgical has been started isometric physiotherapy with flexion and extension of the knee from 0 to 90 degrees plus strengthening of the iliac psoas and quadriceps and resume his activities in 2 months after his surgery.

Conclusion: At present, there is no consensus on the optimal surgical technique due to the lack of clinical trials. More studies of higher quality and sample size are necessary to establish the Gold Standard in the treatment of tibial spine fractures. However, we found that by using Herbert-type compression screws, timely compression of the fracture fragment is achieved in the anatomical reduction. An updated review of the subject and its therapeutic management is carried out. 